\title{
EFEKTIVITAS MANIPULASI EFFLEURAGE TERHADAP TINGKAT DEPRESI PADA LANSIA
}

\author{
Muhammad Nurul Anwar ${ }^{1}$ dan Cerika Rismayanthi ${ }^{1}$ \\ ${ }^{1}$ Fakultas Ilmu Keolahragaan Universitas Negeri Yogyakarta, Jl. Colombo No. 1, Karangmalang Depok, \\ Sleman, Yogyakarta, Indonesia \\ muhammad.nurul@student.uny.ac.id, cerika@uny.ac.id
}

\begin{abstract}
Abstrak
Lansia merupakan tahap lanjut dari proses kehidupan yang ditandai dengan menurunnya kemampuan tubuh untuk beradaptasi dengan lingkungan disekitarnya. Masa lansia merupakan tahap akhir dalam siklus perkembangan manusia di masa proses penuaan yang dialami oleh lansia dapat menyebabkan hilangnya kemampuan organ dan jaringan untuk memperbaiki diri secara perlahan-lahan dan semakin besarnya tekanan batin dan perasaan yang dialami. Tingkat aktivitas yang dilakukan oleh lansia kebanyakan merupakan aktivitas fisik ringan tetapi tetap dapat mendorong dan mempertahankan kemampuannya secara baik. Lansia banyak menghadapi masalah kesehatan yang perlu penanganan segera dan terintregasi. Pada lansia akan mengalami berbagai penurunan, yaitu kekuatan massa otot, menurunnya fungsi neuromuscular terutama pada persendian dan banyaknya mengeluh kelentukan yang berkurang karena kelelahan otot pada tubuh. Seiring dengan adanya penurunan kemampuan pada lansia sering munculnya perasaan cemas dan adanya pola pikir yang semakin dalam. Penelitian ini merupakan penelitian deskrpitif yang bertujuan memberikan apakah terdapat efektivitas massage Effleurage terhadap tingkat depresi pada lansia di dusun Plumbon, Banguntapan, Bantul. Teknik analisis data yang digunakan adalah deskriptif dangan persentase, bertujuan untuk mengumpulkan data, menyajikan data dan menentukan nilai. Hasil penelitian menyatakan bahwa tingkat efektivitas manipulasi effleurage terhadap tingkat depresi pada Lansia adalah baik dengan pertimbangan rerata sebesar 5,6. Tingkat efektivitas massage effleurage terhadap tingkat depresi pada Lansia yang berkategori normal 10 orang atau $66,67 \%$, ringan 5 orang atau 33,33\%.
\end{abstract}

Kata kunci: effleurage, depresi, lansia

\section{EFFECTIVENESS OF MANIPULATION EFFLEURAGE DEPRESSION LEVELS IN ELDERLY}

\begin{abstract}
Elderly is an advanced stage of the life process marked by a decrease in the body's ability to adapt to the surrounding environment. The elderly is the final stage in the cycle of human development during the aging process experienced by the elderly can cause the loss of the ability of organs and tissues to repair themselves slowly and the increasing amount of inner pressure and feelings experienced. The level of activity undertaken by the elderly is mostly mild physical activity but can still encourage and maintain their abilities properly. Elderly faces many health problems that need to be handled immediately and integrated. In the elderly will experience a variety of decreased, namely the strength of muscle mass, decreased neuromuscular function, especially in the joints and the number of complaints of reduced flexibility due to muscle fatigue in the body. Along with a decrease in ability in the elderly often the emergence of feelings of anxiety and the existence of a deeper mindset. This research is a descriptive study aimed at providing whether there is an effectiveness of Effleurage massage on the level of depression in the elderly in the village of Plumbon, Banguntapan, Bantul. The data analysis technique used is descriptive with percentages, aiming to collect data, present data and determine values. The results of the study stated that the level of effectiveness of effleurage manipulation on the level of depression in the elderly was good with a mean consideration of 5.6. The effectiveness
\end{abstract}


of massage effleurage on the level of depression in the elderly is in the normal category of 10 people or $66.67 \%$, mild 5 people or $33.33 \%$.

Keywords: effleurage, depression, elderly

\section{PENDAHULUAN}

Lanjut usia merupakan kelompok umur pada manusia yang telah memasuki tahapan akhir dari fase kehidupannya. Lanjut usia adalah merupakan tahap akhir perkembangan pada kehidupan manusia (Keliat, 1999: 3) dengan terjadinya penurunan kondisi fisik atau biologis, kondisi psikologis, serta perubahan kondisi sosial. Sedangkan pasal 1 ayat (1), (3), (4) UU No. 13 tahun 1998 tentang kesehatan dikatakan bahwa lansia merupakan seseorang yang telah mencapai usia lebih dari 60 tahun. Pria dan wanita yang berusia enam puluh tahun ke atas atau yang biasanya disebut dengan lansia, adalah orang-orang beresiko untuk merasakan kesepian (Hurlock, 1997: 54). Usia lanjut atau yang disingkat lansia adalah seseorang yang berusia 60 tahun atau lebih (Depkes RI, 2000: 4). WHO, lansia merupakan seseorang yang berusia 65 tahun ke atas untuk Amerika Serikat dan Eropa Barat. Sedangkan di Negara-negara Asia, lansia adalah seseorang yang berusia 60 tahun ke atas. Lansia sebagai tahap akhir siklus kehidupan merupakan tahap perkembangan normal yang akan dialami oleh setiap individu yang mencapai usia lanjut dan merupakan kenyataan yang tidak dapat dihindari. Lansia adalah kelompok orang yang sedang mengalami suatu proses perubahan yang bertahap dalam jangka waktu beberapa dekade (Notoatmodjo, 2007: 6). Berdasarkan pendapat tentang lansia di atas, maka dapat disimpulkan bahwa lansia adalah seorang pria atau wanita yang telah menginjak usia dewasa akhir yang ditunjukkan dengan adanya penurunan kondisi fisik atau biologis, kondisi psikologis, serta perubahan kondisi sosial.

Penurunan fungsi kinerja organ dan bagian tubuh vital dari lansia menjadi tanda yang sangat mencolok pada masa lansia ini. Perubahan dari kemampuan mampu melakukan kegiatan dan aktivitas berat menjadi hanya dapat melakukan kegiatan yang memiliki tingkat intensitas dan frekuensi yang ringan. Adanya harapan hidup yang lebih baik tersebut memberikan semangat pada lansia untuk tetap dapat beraktivitas sebaik mungkin. Proses penuaan dan penurunan fungsi organ vital menjadi hal yang sangat penting untuk tetap diberikannya penjagaan untuk dapat tetap memiliki tingkat kebugaran yang maksimal pada tingkat masa usia lanjut tersebut. Menurunnya kemampuan seperti kekuatan dan kecepatanpada usia lanjut menjadi hal yang wajar. Akan tetapi, dengan melakukan aktivitas olahraga yang terukur dan terprogram dengan baik diharapkan dapat membantu mempertahankan fungsi kinerja organ vital pada lansia seperti kinerja jantung dan paru-paru. Menurunnya fungsi paru-paru akan mempengaruhi tingkat aktivitas yang dilakukan oleh lansia, di mana lansia akan merasakan kelelahan dan jantung lebih cepat berdebar kencang maksimal. Keadaan ini tentunya akan menurunkan mental dan kualitas aktivitas lansia untuk tetap tampil bugar dan sehat.

Menurunnya metabolisme tubuh seseorang merupakan sesuatu yang pasti terjadi. Hanya saja, cepat atau lambatnya penurunan itu sangat bergantung pada kebiasaan hidup seseorang. Penurunan system metabolisme tubuh seseorang itu umumnya dimulai saat berusia 50 tahun. Menurunnya fungsi organ tubuh tersebut tentunya akan sedikit merubah kinerja organ yang dilakukan oleh lansia. Selain kualitas hidup yang tetap baik seperti diharapkan oleh lansia sedikit terganggu. Keinginan untuk tetap tampil bugar dan sehat tentunya harus diimbangi oleh kualitas aktivitas fisik yang disesuaikan dengan usia dan tingkat kemampuan yang masih dapat dilakukan oleh lansia.

Salah satu penurunan fungsi yang dialami oleh lansia adalah sistem kardiovaskuler atau pernafasan, dan sistem neuromuskuler yang berhubungan dengan fleksibilitas. Penurunan tersebut meliputi menurunnya kekuatan otot-otot pernafasan maupun otot-otot utama, menurunnya aktifitas silia di dalam hidung, menurunnya elastisitas jantung paru, tulang-tulang 
pembentuk dinding dada mengalami pengeroposan. Sehingga menyebabkan jumlah udarapernafasan yang masuk ke dalam paru-paru berkurang. Sehingga lebih komplek perlu adanya latihan di usia lanjut untuk mencegah terjadinya permasalahan yang komplek.

Kelelahan dalam bekerja terkadang bisa dianggap sebagai tanda adanya sakit yang ada pada tubuh lansia. Akan tetapi, keadaan tersebut bisa saja karena pada lansia terbawa oleh situasi pemikiran dan perasaan cemas sehingga lansia merasa gelisah karena mengalami kelelahan. Kelelahan pada lansia dapat sangat cepat dirasakan ketika setelah bekerja dengan intensitas sedang ke berat. Kelelahan yang dirasakan tersebut akan membawa suasana yang kurang menenangkan pada lansia. Kemungkinan yang dapat terjadi yaitu pola pikir yang berlebihan karena rasa takut pada lansia yang bisa berubah menjadi stres dalam memikirkan. Dalam hal ini peneliti memilih memberikan rangsangan pada lansia berupa manipulasi effleurage untuk dapat membantu mengurangi ketegangan otot dan mengurangi rasa sakit yang dialami oleh lansia. Pemberian rangsangan ini diberikan sesuai dengan kebutuhan lansia dengan kebutuhan relaksasi pada organ tubuh agar tidak memiliki perasaan cemas dan pikiran yang berkepanjangan.

\section{METODE}

Penelitian ini merupakan penelitian Pre-experimen design yang bertujuan untuk menghubungkan kualitas atau sebab-akibat. Desain yang digunakan dalam penelitian ini yaitu Pre-experimental design dengan pendekatan One - Shoot Case Study (Studi Kasus Satu Tembakan), yaitu dalam desain penelitian ini terdapat suatu kelompok diberi treatment (perlakuan) dan selanjutnya diobservasi hasilnya (treatment adalah sebagai variabel independen dan hasil adalah sebagai variabel dependen). Dalam eksperimen ini subjek perlakuan massage lalu diukur hasilnya.

Populasi dalam penelitian ini adalah seluruh lansia laki-laki yang mengikuti perkumpulan di komplek Masjid Al Mahtadin dusun Plumbon, Banguntapan, Bantul. Populasi yang terdapat di perkumpulan di komplek Masjid Al Mahtadin terdapat 80 orang. Teknik pengambilan sampel dalam penelitian ini adalah purposive sampling. Purposive sampling yaitu suatu teknik pengambilan sampel berdasarkan dengan teknik digunakan untuk mencapai tujuan-tujuan tertentu, Hadi (2004: 186). Kriteria yang digunakan dalam penelitian ini sebagai berikut: (a) lansia yang berjenis kelamin laki-laki, (b) lansia yang berusia 45-65 tahun (Depkes RI; 2009), (c) lansia laki-laki yang mengikuti perkumpulan di masjid Al Muhtadin, (b) lansia yang mengalami gangguan kesehatan ringan, seperti: rematik, hipertensi, insomnia, dll. Berdasarkan kriteria tersebut maka diperoleh responden yang memenuhi kriteria sebesar 15 orang. Mengetahui skor tingkat depresi lansia, bisa dilihat di indeks tingkat depresi dalam penelitian Supratmanto (2018: 67) di bawah ini sebagai berikut:

Tabel 1. Indeks Tingkat Depresi

\begin{tabular}{|c|c|c|c|}
\hline Tingkatan & Depresi & Kecemasan & Stres \\
\hline Normal & $0-9$ & $0-7$ & $0-14$ \\
\hline Ringan & $10-13$ & $8-9$ & $15-18$ \\
\hline Sedang & $14-20$ & $10-14$ & $19-25$ \\
\hline Parah & $21-27$ & $15-19$ & $26-33$ \\
\hline Sangat parah & $28-42$ & $20-42$ & $34-42$ \\
\hline
\end{tabular}

(Sumber: Soerjono dkk, 2007: 45)

Indeks di atas untuk mengukur tingkat depresi dengan menilai skala item depresi, sehingga mengetahui tingkat depresi dengan melihat indeks ukur kelompok depresi yang ada tabel di atas. Pengumpulan data akan dilakukan setelah dilakukan perlakuan massage, menggunakan metode survey dan pemberian rangsangan. Adapun mekanisme pengumpulan data yaitu 
diberikannya massage Effleurage kemudian dilakukan tes akhir berupa pengisian angket efektivitas massage pada hari berikutnya setelah diarahkannya efek dari perlakuan atau rangsangan.

\section{HASIL DAN PEMBAHASAN}

Hasil penelitian tentang efektivitas manipulasi effleurage terhadap tingkat depresi, kecemasan dan stres pada lansia di perkumpulan di komplek Masjid Al Muhtadin dusun Plumbon, Banguntapan, Bantul. Penelitian ini dilakukan pada Selasa, 30 september 2018 dengan responden sebanyak 15 orang. Dari hasil di atas akan dideskripsikan sebagai berikut:

Tabel 2. Deskripsi Statistik Efektivitas Manipulasi Effleurage Terhadap Tingkat Depresi

\begin{tabular}{|l|c|}
\hline \multicolumn{1}{|c|}{ Statistik } & Skor \\
\hline Mean & 5,6000 \\
\hline Median & 4,0000 \\
\hline Mode & $1,00^{\mathrm{a}}$ \\
\hline Std. Deviation & 5,09622 \\
\hline Range & 25,971 \\
\hline Minimum &, 00 \\
Maximum & 13,00 \\
\hline
\end{tabular}

Dari data di atas dapar dideskripsikan efektivitas manipulasi effleurage terhadap tingkat depresi pada Lansia di perkumpulan di Komplek Masjid Al Muhtadin dusun Plumbon, Banguntapan, Bantul dengan rerata sebesar 5,60, nilai tengah sebesar 4,00, nilai sering muncul sebesar 1,00 dan simpangan baku sebesar 5,09. Sedangkan skor tertinggi sebesar 13 dan skor terendah sebesar 0,00. Dari hasil tes maka dapat dikategorikan efektivitas manipulasi effleurage terhadap tingkat depresi pada Lansia di perkumpulan di Komplek Masjid Al Muhtadin dusun Plumbon, Banguntapan, Bantul. Perhitungan tersebut disajikan dalam tabel sebagai berikut:

Tabel 3. Kategorisasi Efektivitas Manipulasi Effleurage Terhadap Tingkat Depresi

\begin{tabular}{|c|c|c|c|c|}
\hline \hline No & Interval & Frekuensi & Persentase $(\%)$ & Kategori \\
\hline 1 & $0-9$ & 10 & 66,67 & Normal \\
\hline 2 & $10-13$ & 5 & 33,33 & Ringan \\
\hline 3 & $14-20$ & 0 & 0,00 & Sedang \\
\hline 4 & $21-27$ & 0 & 0,00 & Parah \\
\hline 5 & $28-42$ & 0 & 0,00 & Sangat Parah \\
\hline & Jumlah & 15 & 100 & \\
\hline
\end{tabular}

Dari tabel di atas dapat diketahui bahwa tingkat efektivitas manipulasi effleurage terhadap tingkat depresi pada Lansia di perkumpulan di Komplek Masjid Al Muhtadin dusun Plumbon, Banguntapan, Bantul adalah baik dengan pertimbangan rerata sebesar 5,6. Tingkat efektivitas massage effleurage terhadap tingkat depresi pada Lansia di perkumpulan di Komplek Masjid Al Muhtadin dusun Plumbon, Banguntapan, Bantul yang berkategori normal 10 orang atau $66,67 \%$, ringan 5 orang atau 33,33\%, sedang 0 orang atau $0 \%$, parah 0 orang atau $0,00 \%$ dan sangat parah 0 orang atau $0,00 \%$. Berikut adalah grafik tingkat efektivitas manipulasi effleurage terhadap tingkat depresi pada Lansia di dusun Plumbon, Banguntapan, Bantul. 


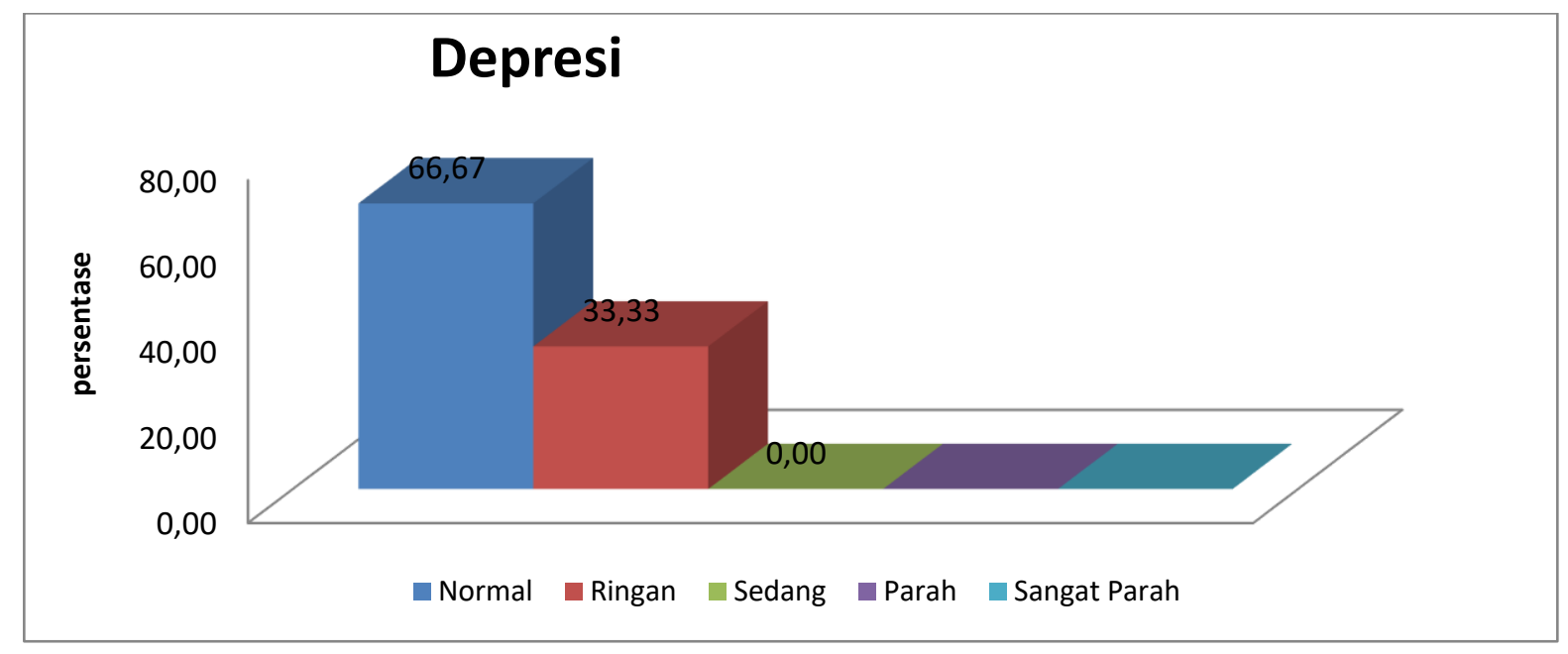

Gambar 1. Tingkat efektivitas manipulasi effleurage terhadap tingkat depresi

Dari deskripsi hasil penelitian yang dilakukan tentang tingkat efektivitas manipulasi effleurage terhadap tingkat depresi pada Lansia perkumpulan di Komplek Masjid Al Muhtadin dusun Plumbon, Banguntapan, Bantul bahwa tingkat efektivitas manipulasi effleurage terhadap tingkat depresi pada Lansia di dusun Plumbon, Banguntapan, Bantul adalah baik dengan pertimbangan rerata sebesar 5,6. Tingkat efektivitas manipulasi effleurage terhadap tingkat depresi pada Lansia di dusun Plumbon, Banguntapan, Bantul yang berkategori normal 10 orang atau $66,67 \%$, ringan 5 orang atau 33,33\%, sedang 0 orang atau $0 \%$, parah 0 orang atau $0,00 \%$ dan sangat parah 0 orang atau 0,00\%. Tingkat efektivitas manipulasi effleurage terhadap tingkat kecemasan pada Lansia di dusun Plumbon, Banguntapan, Bantul adalah baik dengan pertimbangan rerata sebesar 5,26.

Berdasarkan hasil penelitian tersebut bahwa tingkat depresi, kecemasan dan stres pada lansia setelah mendapat rangsangan manipulasi effleurage berada pada kategori normal. Hal ini menunjukkan bahwa pemberian perlakuan rangsangan manipulasi effleurage dapat memberikan kontribusi yang efektif terhadap pengontrolan tingkat depresi, kecemasan dan stres pada lansia. Keluhan yang dirasakan oleh lansia sebelum diberikan perlakuan massage menjadi perhatian tersendiri dikarenakan lansia mengalami hal yang kurang nyaman dirasakan pada tubuh lansia. Selain itu, dengan diadakannya perlakuan terhadap keluhan pada lansia berupa manipulasi effleurage memberikan harapan pada lansia terhadap penanganan keluhan. Hal ini dapat dilihat terhadap minat lansia untuk berkenan dilakukan manipulasi effleurage. Pemberian rangsangan ini tidak hanya bertujuan untuk mengurangi keluhan saja tetapi secara psikologi akan mengurangi depresi, kecemasan dan stres pada lansia. Kecenderungan untuk terjadi kecemasan, depresi dan stres pada lansia dapat muncul akibat perasaan yang berlebih akbiat dari rasa sakit atau gangguan pada organ tubuh dengan skala ringan sampai berat. Aktivitas yang terganggu tentunya akan memberikan pandangan dan tanggapan yang berbedabeda pada lansia sehingga gangguan kecemasan, depresi dan stres dapat terjadi. Belum adanya penanganan dan stimulus yang diberikan, akan menambah perasaan yang lebih dalam bagi lansia yang timbul akibat gangguan tersebut. Adanya waktu dan ruang untuk melepas dan meringankan keluhan tersebut diharapkan akan membantu lansia untuk kembali lepas dari gangguan sakit maupun gangguan perasaan tersebut.

Proses relaksasi dengan memberikan rangsangan pada lansia setelah lelah melakukan aktivitas keseharian dapat memberikan efek yang baik bagi tubuh lansia. Pemberian rangsangan berupa massage tentunya akan membantu mengurangi ketegangan otot dan memberikan rangsangan yang baik pada tubuh yang kelelahan. Adanya rangsangan yang memberikan efek positif tersebut diharapkan dapat mengurangi perasaan cemas dan pola pikir berlebihan yang bisa berakibat stres pada lansia. Perasaan tenang yang setelah dilakukannya rangsangan 
massage tersebut akan membantu lansia untuk memiliki kepercayaan diri untuk terus beraktivitas tanpa merasakan khawatir. Selain itu dengan adanya rangsangan tersebut diharapkan lansia juga tidak berpikir yang macam-macam berkepanjangan sehingga dapat berpikir positif.

\section{SIMPULAN}

Dari penelitian diatas dapat disimpulkan bahwa manipulasi effleurage dapat mengurangi depresi, kecemasan dan stres pada lansia. Lansia merasa lebih tenang dan bugar setelah diberikan rangsangan berupa massage sehingga lansia lebih percaya diri dan lebih fit dalam melakukan aktivitas sehari-hari.

\section{DAFTAR PUSTAKA}

Anderson, M.K. \& Parr, G.P. (2011). Fundamentals of Sport Injury Management. Philadelphia: Lippincott Williams \& Wilkins, Wolter Kluwer.

Arovah, N.I. (2010). Diagnosa dan Manajemen Cedera Olahraga. Yogyakarta: FIK UNY.

Asmadi. (2008). Teknik Prosedural Konsep dan Aplikasi Kebutuhan Pasien. Jakarta: Salemba Medika https://books.google.co.id diunduh pada hari senin, 4 Februari 2018

Fondy, T. (2012). Merawat dan Mereposisi Cedera Tubuh. Banten: Pustaka Tumbur Helmi, Z.N. (2012). Buku Ajar Gangguan Muskuloskeletal. Jakarta Selatan: Salemba Medika. Junge, A. \& Dvorak, J. (2014). Injury Risk of Playing Football in Futsal World Cups. Journal. Switzerland: Br J Sport Med, 1089-1092.

Malanga, G.A., Yan, Ning., and Stark, Jill. (2015). Mekanisms and Efficacy of Heat and Cold Therapies for Musculoskeletal Injury. USA: Postgraduate Medicine.

Nadler, Scott F. DO, FACSM, Weingand, K., \& Kruse, R.J. (2004). The Physiologic Basic and Clinical Application of Cryotherapy and Thermotherapy for the Pain Practitioner. Pain Physician, 7, (3). 395-399.

Nurjanah, Siti. (2016). Keefektifan Kombinasi Terapi Panas dan Dingin dengan Terapi Panas, Terapi Dingin terhadap Cedera Otot Hamstring. Skripsi. Yogyakarta: FIK UNY.

Nurkhasanah, S. \& Fetrisia, W. (2014). Pengaruh Masase Effleurage Terhadap Penurunan Intensitas Skala Nyeri Disminore pada Siswi Kelas IX MTsN 1 Bukittinggi tahun 2014. Jurnal Kesehatan. Bukittinggi: STIKes Prima Nusantara Bukittinggi 5 (2), 27-28.

Ambardini, R.L. \& Kushartanti, B.M.W. (2016). Efektivitas Masase Topurak untuk Reposisi Subluksasi Bahu. Proceedings FIK UNY. Hlm 73-82.

Peterson, L. \& Renstrom, P. (2001). Sport Injuries Theie prevention and Treatment. UK: Martin Dunitz Ltd.

Roenn, P.V., Paice A.J., \& Preodor E.M. (2006). Current Diagnosis \& Treatment of Pain. USA: The McGraw-Hill Companies, Inc.

Setiawan, A. (2015). Sport Massage: Pijat Kebugaran. Yogyakarta: Magnum Pustaka Utama Wijanarko, B. \& Slamet, R. (2010). Sport Massage: Teori dan Praktek. Surakarta: Yuma Pustaka

Wilson, F., Gormley, J., \& Hussey, J. (2011). Exercise Therapy in the Management of Musculoskeletal Disorders. UK: Wiley Blackwell Ltd. 